\title{
Factors That Influence the Entrepreneurial Intention of Nigerian Postgraduates: Preliminary Analysis and Data Screening
}

\author{
Mahmoud Ahmad Mahmoud ${ }^{1}$, Farrah Merlinda Muharam ${ }^{1} \&$ Abdulsalam Mas'ud ${ }^{1,2}$ \\ ${ }^{1}$ College of Business, Universiti Utara Malaysia, Malaysia \\ ${ }^{2}$ Hussaini Adamu Federal Polytechnic, Kazaure, Jigawa State, Nigeria \\ Correspondence: Mahmoud Ahmad Mahmoud, College of Business, Universiti Utara Malaysia, Sintok, Kedah, \\ Malaysia. Tel: 60-16-958-0322; 234-706-194-7777. E-mail: elmahmuud@yahoo.com
}

$\begin{aligned} & \text { Received: September 30, } 2014 \quad \text { Accepted: December 18, } 2014 \quad \text { Online Published: January 14, } 2015 \\ & \text { doi:10.5539/ass.v11n4p180 }\end{aligned} \quad$ URL: http://dx.doi.org/10.5539/ass.v11n4p180

\begin{abstract}
The aim of this paper is to conduct a preliminary analysis and Data screening with relation to the effect of Attitude, subjective norm and perceived behavioural control, on the entrepreneurial Intentions of Nigerian Postgraduates. 240 Master and $\mathrm{PhD}$ candidates were surveyed from Universiti Utara Malaysia (UUM) and the study utilized the convenience sampling method, which result to 156 respondents. The study was equally conducted to suit the multivariate analysis assumptions. Using the Statistical Package for Social Science (SPSS) software version 20, the univariate and multivariate outliers are checked and treated, the check for missing Data was performed, so also the kurtosis and skewness, factor analysis and the reliability test of the cronbach coefficient alpha. The data was finally ready for the multivariate analysis as it fulfilled the necessary assumptions for that. The findings are therefore important to the study and that of other researchers whom will benefit from the literature to conduct data screening and preliminary analysis.
\end{abstract}

Keywords: attitude, subjective norm, perceived behavioural control, entrepreneurial intention, data screening, postgraduates and Nigeria

\section{Introduction}

Economic development will be absent unless there is a growth in venture creation that will improve employment availability. Venture creation is thus, a significant terminal for job creation among both developed and developing nations (Owoseni, 2014; Uddin \& Bose, 2012). Entrepreneurship therefore, has a significant status in the fast changing global socioeconomic environment (Ali, Topping, \& Tariq, 2010). The interest of policy makers in entrepreneurial development is growing (Davey, Plewa, \& Struwig, 2011; Karabulut, 2014; Owoseni, 2014). Government and other institution's efforts are evidence for that (Karabulut, 2014). Nonetheless, business creation is a cumbersome decision due to its nature of voluntary process with conscious intention (Linan, Nabi, \& Krueger, 2013).

Despite the mounting rate of unemployment and the effect of such to crimes, law and order, (Owoseni, 2014) only a few studies were conducted on entrepreneurial intentions in the developing countries (Nabi \& Linan, 2011; Sandhu, Sidique, \& Riaz, 2011). Specifically, Nigeria is lacking empirical researches on entrepreneurial intentions (Izedonmi \& Okafor, 2010).

According to Agbim, Oriarewo, and Owocho, (2013) a lot of contemporary studies revealed the average entrepreneur to be more educated than the ordinary man. Therefore, studies on entrepreneurial career intentions are plenty on university students but only a few are conducted on graduate schools (Karabulut, 2014) and or postgraduate candidates (Sandhu et al., 2011).

\section{Literature Review}

Intention is the best predictor of behaviour thus; it can predict the process of venture creation (Krueger, Reilly, \& Carsrud, 2000). Venture creation, is not likely to take place without intention (Owoseni \& Akambi, 2010). Attitudes, subjective norms and perceived behavioural control are described as the antecedents of intention (Ajzen, 1991). Thus, they can influence the entrepreneurial intention and behaviour of people.

Attitude is the degree that an individual perceived the allurement of a specific behaviour (Bakotic \& Kruzic, 
2010). Entrepreneurial attitude is therefore, the extent of one's positive valuation of inventing and starting a new business (Linan et al., 2013). Attitudes are found to have a strong significant relationship with entrepreneurial intentions by Angriawan, Conners, Furdek, and Ruth, (2012); Kolvereid and Isaksen (2006); Kuttim, Kallastea, Venesaara, and Kiis, (2014); Linan and Chen, (2009); Linan, Rodriguez-Cohard, and Rueda-Cantuche, (2011); Linan et al., (2013); Mahmoud and Muharam, (2014); Malebana, (2014); Mueller, (2011); Otuya, Kibas, Gichira, and Martin, (2013); Souitaris, Zerbinati and Al Laham, (2007); Zampetakis, Anagnosti, and Rozakis, (2013);

Subjective norm is the perceived social pressure to conduct or otherwise a specific behaviour (Ajzen, 1991). It is the ken of other people on the specific behaviour in question which are known as the perceived social desirability (Owoseni \& Akambi, 2010). Subjective norms, therefore reflect the force, influence, and approbation of others that are important for creating a firm (Linan et al., 2013). Subjective norms are found to be influential on entrepreneurial intentions by Angriawan et al., (2012); Kautonen Marco, and Erno, (2012); Kolvereid and Isaksen (2006); Mahmoud and Muharam, (2014); Malebana (2014); Sahindis Giovanis, and Sdrolias, (2012); and Souitaris et al., (2007).

Perceived behavioural control is the perceived ease or impediment of performing a given behaviour (Ajzen, 1991). A person that feels competent will be more likely to accept starting a new business is feasible (Krueger et al., 2000). Thus, perceived behavioural control is measuring the ken of hardship or ease of creating a business (Linan et al., 2013). Many studies revealed that the perceived behavioural control is an important predictor of entrepreneurial intentions see for instance; Ekpe and Mat, (2013); Iakovleva, Kolvereid, and Stephan, (2011); Linan et al., (2011); Linan et al., (2013); Mahmoud and Muharam, (2014); Malebana (2014); Ogundipe, Kosile, Olaleye, and Ogundipe, (2012); Otuya et al., (2013).

\section{Methodology}

The study utilized the quantitative survey method and the data was analysed using the descriptive and inferential statistics with the aid of SPSS version 20.

\subsection{Population}

The study population covers the 240 Nigerian postgraduate candidates of UUM which consist of the three graduate colleges of the university which are the College of Business (COB), College of Legal and International Studies (COLGIS) and the College of Arts and Sciences (CAS). Out of this 240 candidates, 157 are from COB, 49 candidates from CAS and 34 from COLGIS.

\subsection{Sampling}

The Krejcie and Morgan (1970) sampling table was used to ascertain the representative sample, the table states that the representative sample for a population of 240 should be 148, thus, the study pick 156 sample which satisfy the minimum requirement for the representative sample. The convenient sampling method was however used to collect the data, while ensuring that candidates from all the three colleges of the University are included in the survey.

\subsection{Response Rate}

Out of the 190 questionnaires that have been distributed to the population of 240 postgraduate candidates, 156 of the questionnaires were returned indicating a response rate of $82 \%$. The 156 respondents represent exactly $65 \%$ of the population and have fulfilled the requirements of a representative sample of the population which was calculated to be not less than 148 of the 240 candidates by Krejcie and Morgan (1970).

\section{Findings and Discussion}

The findings and analysis of the personal background of the respondents, as well as other preliminary analysis will be discussed in this section.

\subsection{Descriptive Analysis}

The descriptive analysis was utilized to analyse the profile of the respondents. This includes gender, age, college of study, programme of study, semester of study, work experience, ownership of self-business, family members that run a business, and role model. The result as shown in Table 1 consists of 150 male (96.2\%), 6 female (3.8\%). For the whole respondents, $98(62.8 \%)$ are between the ages of 20-35 years, $54(34.6 \%)$ are between the ages of 36-45 years, $4(2.6 \%)$ are of 46 years and above. COB/OYAGSB has $109(69.9 \%)$, COLGIS has 20 $(12.8 \%)$ and CAS has $27(17.3 \%)$. The respondents that study Masters are $50(32.1 \%), \mathrm{PhD} 106(67.9 \%)$ and zero for DBA. Those in the first semester are $28(17.9 \%)$, second semester has $45(28.8 \%)$, third semester has 47 (30.1\%), fourth semester has $17(10.9 \%)$, fifth semester has $17(10.9 \%)$ and the sixth semester has $2(1.3 \%)$. The respondents that have work experience are $150(96.2 \%)$ and those that have no work experience are $6(3.8 \%)$. 
Those who have ever owned a business are 111 (71.2\%) and those that do not are 45 (28.8\%). Those whose family members run a business are $140(89.7 \%)$ and those that do not are $16(10.3 \%)$. The respondents that have a role model on self-business are $122(78.2 \%)$ those that have no role model are $34(21.8 \%)$.

Table 1. Descriptive results for the respondent's profile

\begin{tabular}{|c|c|c|c|}
\hline S/No & Items & Frequency $(\mathrm{N}=156)$ & Percentages (\%) \\
\hline \multirow{3}{*}{1} & Gender & & \\
\hline & Male & 150 & 96.2 \\
\hline & Female & 6 & 3.8 \\
\hline \multirow{4}{*}{2} & Age & & \\
\hline & $20-35$ & 98 & 62.8 \\
\hline & $36-45$ & 54 & 34.6 \\
\hline & 46 and above & 4 & 2.6 \\
\hline \multirow{4}{*}{3} & College of study & & \\
\hline & $\mathrm{COB} / \mathrm{OYGSB}$ & 109 & 69.9 \\
\hline & COLGIS & 20 & 12.8 \\
\hline & CAS & 27 & 17.3 \\
\hline \multirow{4}{*}{4} & Program of study & & \\
\hline & Masters & 50 & 32.1 \\
\hline & $\mathrm{PhD}$ & 106 & 67.9 \\
\hline & DBA & 0 & 0 \\
\hline \multirow{7}{*}{5} & Semester of study & & \\
\hline & 1 & 28 & 17.9 \\
\hline & 2 & 45 & 28.8 \\
\hline & 3 & 47 & 30.1 \\
\hline & 4 & 17 & 10.9 \\
\hline & 5 & 17 & 10.9 \\
\hline & 6 & 2 & 1.3 \\
\hline \multirow{3}{*}{6} & Work experience & & \\
\hline & Yes & 150 & 96.2 \\
\hline & No & 6 & 3.8 \\
\hline \multirow{3}{*}{7} & Ownership of self-business & & \\
\hline & Yes & 111 & 71.2 \\
\hline & No & 45 & 28.8 \\
\hline \multirow{3}{*}{8} & Family members that run a business & & \\
\hline & Yes & 140 & 89.7 \\
\hline & No & 16 & 10.3 \\
\hline \multirow{3}{*}{9} & Role model & & \\
\hline & Yes & 122 & 78.2 \\
\hline & No & 34 & 21.8 \\
\hline
\end{tabular}

\subsection{Test of Non-response Bias}

The non-response bias is important for the study because, there is a bias possibility which need to be scrutinized irrespective of the small amount of a non-response (Sheikh, 1981). The mistake of which the researcher expects to perform during the estimation of a sample characteristics due to the under representation of some group of respondents as a result of non-response is referred to as non-response bias (Berg, 2002). Singer, (2006, p. 641) states that "there is no minimum or maximum response rate below or above which a survey estimate is biased or never biased".

The respondents are classified in to the early response and the late response. This classification was tied to the four variables of the study (Attitudes, Subjective norms, Perceived Behavioural Control and Entrepreneurial Intention). The questionnaire was first distributed in the second week of August thus, the study test the 
nonresponse bias of those that responded within August (early response) and those that respond in September (late response). From Table 2 below, the range mean and standard deviation for both the early and late response are varied distinctly. In Table 3 the $t$ test for the two tailed result depicts an insignificant difference with the early respondents with Attitude (t 1.350, $\mathrm{p}<0.179$ ), Subjective norms (t 1.027, $\mathrm{p}<0.306$ ), Perceived Behavioural Control (t 1.692, $\mathrm{p}<0.093)$, and Entrepreneurial intention ( $\mathrm{t} 0.176, \mathrm{p}<0.871)$.

Table 2. Descriptive statistics for early respondents and late respondents

\begin{tabular}{llllll}
\hline Variables & Response & N & Mean & Std. Deviation & Std. Error Mean \\
\hline \multirow{2}{*}{ ATT } & Early Response & 63 & 6.0222 & 1.20435 & .15173 \\
& Late Response & 93 & 5.7892 & .94656 & .09815 \\
SN & Early Response & 63 & 5.6138 & 1.24031 & .15626 \\
& Late Response & 93 & 5.4301 & .98611 & .10226 \\
PBC & Early Response & 63 & 5.5556 & .97504 & .12284 \\
& Late Response & 93 & 5.2980 & .90318 & .09366 \\
EIN & Early Response & 63 & 5.7540 & 1.27909 & .16115 \\
& Late Response & 93 & 5.7240 & .84252 & .08737 \\
\hline
\end{tabular}

Table 3. Independent samples T-test for equality of means Leven' Test for equality of variance

\begin{tabular}{|c|c|c|c|c|c|c|c|c|c|c|}
\hline Variables & & F & Sig. & $\mathrm{T}$ & Df & $\begin{array}{l}\text { Sig. (2 } \\
\text { tailed) }\end{array}$ & $\begin{array}{l}\text { Mean } \\
\text { Difference }\end{array}$ & $\begin{array}{l}\text { SD Error } \\
\text { Difference }\end{array}$ & $\begin{array}{l}95 \\
\text { Confidence } \\
\text { of the } \\
\text { difference } \\
\text { Lower }\end{array}$ & $\begin{array}{l}\text { Interval } \\
\text { Upper }\end{array}$ \\
\hline \multirow[b]{2}{*}{ ATT } & $\begin{array}{l}\text { Equal } \\
\text { variance } \\
\text { (Assumed) }\end{array}$ & .004 & .949 & 1.350 & 154 & .179 & .23297 & .17263 & .10805 & .57400 \\
\hline & $\begin{array}{l}\text { Equal } \\
\text { variance } \\
\text { (Not } \\
\text { assumed) }\end{array}$ & & & 1.289 & 111.578 & .200 & 23297 & .18071 & .12510 & .59105 \\
\hline \multirow[b]{2}{*}{$\mathrm{SN}$} & $\begin{array}{l}\text { Equal } \\
\text { variance } \\
\text { (Assumed) }\end{array}$ & .877 & .351 & 1.027 & 154 & .306 & .18365 & .17877 & .16951 & .53680 \\
\hline & $\begin{array}{l}\text { Equal } \\
\text { variance } \\
\text { (Not } \\
\text { Assumed) }\end{array}$ & & & .983 & 112.557 & .328 & .18365 & .18675 & .18635 & .55365 \\
\hline \multirow[b]{2}{*}{ PBC } & $\begin{array}{l}\text { Equal } \\
\text { variance } \\
\text { (Assumed) }\end{array}$ & .157 & .692 & 1.692 & 154 & .093 & .25755 & .15220 & .04313 & .55823 \\
\hline & $\begin{array}{l}\text { Equal } \\
\text { variance } \\
\text { (Not } \\
\text { Assumed) }\end{array}$ & & & 1.667 & 126.272 & .098 & .25755 & .15447 & .04814 & .56324 \\
\hline \multirow[b]{2}{*}{ EIN } & $\begin{array}{l}\text { Equal } \\
\text { variance } \\
\text { (Assumed) }\end{array}$ & $\begin{array}{l}4.64 \\
6\end{array}$ & .033 & .176 & 154 & .860 & .02995 & .16979 & .30546 & .36537 \\
\hline & $\begin{array}{l}\text { Equal } \\
\text { variance } \\
\text { (Not } \\
\text { Assumed) }\end{array}$ & & & .163 & 98.090 & .871 & .02995 & 18331 & .33381 & .39372 \\
\hline
\end{tabular}




\subsection{Data Prepared for Analysis}

Each of the questionnaires was given a serial number before it is keyed in to the SPSS software. This is to assist in tracing and to facilitate a thorough checking to ensure that the information is entered correctly. The serialization also facilitates the task of distinguishing the earlier and the late respondents.

\subsubsection{Coding}

Coding was made to ease and facilitate the identification of items, thus, all items had been coded to ease keying the data and the analysis. The coding is based on each variable and was recorded accordingly with respect to the constructs.

\subsubsection{Data Editing}

Each questionnaire was checked through during the collection in order to avoid incompleteness; fortunately, all the returned questionnaires are fully answered. This might be related to the level of knowledge of the respondents whom are all postgraduates. Thus, there is no incomplete questionnaire or missing data.

\subsection{Missing Data}

Preventive measures were taken right from the start of the survey in order to avoid or reduce the rate of the missing data. This is due to its effect on the analysis. Thus, the filled questionnaires were properly checked from the start to the end and just after the collection, to ensure that each item is properly responded to. The participant that missed a question(s) should be politely requested to respond to that question properly (Maiyaki \& Moktar, 2011) this will significantly help in reducing the amount of the data that was missed (Gorondutse \& Hilman, 2014).

If the missing data is up to $25 \%$ or more, then it is advised that the questionnaire should be excluded from further analysis (Cavana, Delahaye, \& Sekaran, 2001). According to Hair, Black, Babin, and Anderson, (2010) any case of a missing data that is greater than $50 \%$ should be excluded as extensive as the sample is adequate (Maiyaki \& Moktar, 2011). However, if there is any significant missing data at random, the data should not be used for further analysis and therefore be removed (Maiyaki \& Moktar, 2011).

After the data was keyed into the SPSS software, the descriptive statistics were utilized to examine if there was any data that is missing, the result showed that there are no any missing data values, and therefore the data is good for further analysis.

\subsection{Assessment of Outliers}

Another vital step of screening data is the assessment and treatment of the outliers. Outlier is the excessive case score which might possibly have a notable negative influence on the results (Maiyaki \& Moktar, 2011). Outlier issues usually have an uncommon low or high value, a construct or a unique mixture of values upon numerous constructs, which cause the test stand out from the remnant rest (Hair et al., 2010; Bryn, 2010).

Utilizing the multivariate analysis might consequently prove the detection and treatment of outliers. Both the univariate and the multivariate outliers were examined in this study. The univariate outliers have been examined through detecting the cases with higher z-score values. Thus, any case with the value of a standardized z-score that is above 3.29 is regarded as a potential univariate outlier (Tabachnick \& Fidell, 2007) and thus, 10 cases have been identified and removed.

On the other hand, the Mahalanobis Distance (D) was performed to find and treat the multivariate outlying issues (Hair et al., 2010) with reference to the suggestions of Tabachnick and Fidel (2007). According to Tabachnick and Fidel (2007) the numbers of items used in the study are checked under the chosen degree of freedom in the Chi-square table, in this case 21 items are adopted at the degree of freedom of $\mathrm{P}<0.05$ which revealed the standard to be 32.671. Therefore, any value that has a Mahalanobis Distance of 32.671 or above is regarded as a multivariate outlier that needs to be deleted. Fortunately, there is no single case that has above the standard of 32.671 .

\subsection{Normality}

Screening for normality is a very important step in almost all multivariate analysis so far the final objective of a study is to make inference (Tabachnick \& Fidell, 2007; Hair et al., 2010). According to Tabachnick and Fidell, (2007) Test Normality is concerned with the nature of the circulation of data for a single regular construct and the relationship of that to normal distribution. Hair et al. (2010) and Tabachnick and Fidell, (2007) stated that the most important postulation in the multivariate analysis is the test normality.

The Normality test includes the univariate and the multivariate normality, all of which are treated in this study. 
The values of skewness are found to be below 2, while the values of kurtosis are below 7 . The range of acceptable values of the Skewness is $<2$ and $<7$ for the Kurtosis (Gorondutse \& Hilman, 2014). Thus, the values are within the range of accepting.

If the values are above the acceptability range, the best way to deal with it is by transforming the variable which will enhance the results (Tabachnick \& Fidell, 2007).

Homoscedasticity test is also associated to the normality assumption and that the heteroscedasticity is absent when data is fairly normal thus, the variables relationships are assumed homoscedastic (Tabachnick \& Fidell, 2007). The absence of heteroscedasticity, and the assumption of homoscedasticity are both satisfied in this study as both the univariate and the multivariate normality are verified.

\subsection{Multicollinearity}

According to Maiyaki and Moktar, (2011) multicollinearity will make the analysis weaker; this is because the interrelationship between two or more variables will grow the size of error terms as the interrelated variables will contain unnecessary information. The solution for multicollinearity issue is to delete the interrelated variable (Gorondutse \& Hilman, 2014). The multicollinearity issue will therefore be verified using the Correlation and VIF/tolerance level analysis.

\subsubsection{Correlation Analysis}

To ascertain the direction and strength of the relationship between the variables of this study, the Pearson correlation was utilized. This will help to understand whether there is a threat of multicollinearity or not. According to Tabachnick and Fidell, (2007) the issue of multicollinearity arises when the relationship between the independent variables is up to 0.9 and beyond. The Pearson Correlation analysis is depicted in Table 4 below:

Table 4. Correlation between the study variables

\begin{tabular}{lllll}
\hline S/No & Variables & $\mathbf{1}$ & $\mathbf{2}$ & $\mathbf{3}$ \\
\hline 1 & ATT & 1 & & \\
2 & SN & $.455^{* *}$ & 1 & 1 \\
3 & PBC & $.632^{* *}$ & $.394^{* *}$ & 1 \\
\hline
\end{tabular}

** $<0.001$ (1-tailed); ATT $=$ Attitude, $\mathrm{SN}=$ Subjective Norms, $\mathrm{PBC}=$ Perceived Behavioural Control, EIN $=$ Entrepreneurial Intentions.

From the above table, we can see that none of the variables are up to 0.9 thus, there is no any threat of multicollinearity in consideration to the arguments of Tabachnick and Fidell (2007) and Hair et al., (2010).

\subsubsection{Variance Inflation Factor (VIF)}

Another method for screening the multicollinearity issue is the Variance Inflation Factor (VIF) and the tolerance level, which can be conducted through Regression analysis in the SPSS (Gorondutse \& Hilman 2014). According to Hair et al., (2010) the tolerance value must not exceed 0.10 while the VIF value must not go beyond 10 . When the VIF is less than 10 the result is good enough (Tabachnick \& Fidell 2007). Table 5 will show the VIF and the tolerance value for each of the independent variables.

Table 5. VIF and tolerance values for multicollinearity test

\begin{tabular}{llcc}
\hline S/No & Variables & Tolerance values & VIF \\
\hline $\mathbf{1 .}$ & Attitude & .555 & 1.801 \\
2. & Subjective Norms & .781 & 1.281 \\
3. & Perceived Behavioral Control & $\mathbf{. 5 8 5}$ & $\mathbf{1 . 7 1 0}$ \\
\hline
\end{tabular}

From Table 5 we can see that there is no threat of multicollinearity because the VIF for all the independent variables are less than 10 and the tolerance values are also more than 0.10 . 


\subsection{Factor Analysis for the Variables}

The whole items for this study have been subjected to the Principal Component Analysis (PCA) by the use SPSS software (Hair et al., 2010; Bryn, 2010). Although the items of the study are adopted from past studies, the factor analysis is still important (Gorondutse \& Hilman, 2014).

The results show that all values are $<0.9$ in the correlation matrix, indicating the data has no case of multicollinearity (Hair et al., 2010; Nunally \& Bernstein, 2004). The correlation matrix further shows a number of coefficients with values of $>0.3$ therefore, the first obligation to assess the PCA is fulfilled (Gorondutse \& Hilman, 2014).

Kaiser, (1974) recommended that Kaiser-Meyer-OLkin (KMO) values ranging from 0.5 to 0.7 are mediocre, values from 0.7 to 0.8 are regarded to be good, values from 0.8 and 0.9 are classified to be great while values above 0.9 are termed to be excellent. The result of the KMO measure of sampling adequacy was found to be 0.895 which is above the value of 0.6 that is recommended (Kaiser, 1974, 1970; Maiyaki \& Mouktar, 2011). Thus, the value of 0.895 is a great value and therefore, the data is regarded fit for the factor analysis.

Additionally, the Bartlett's Test of Sphericity revealed a statistically significant value of $\mathrm{P}>0.001$ which sustained the factorability of the correlation matrix, noting some associations between the variables under study. The cumulative variance was 40.696 . However, the result revealed a communality value of above 0.5 for all items with the exception of PBC2 that has 0.494 which is noted to be deleted. This is because, according to Kaiser, (1974) the value of communality for all variables should be $\geq 0.50$. Table 6 below shows the values of communality and the factor loadings for each item.

Table 6. Factor loading and communality for exogenous variables

\begin{tabular}{llcc}
\hline S/No & Items & Loadings & Communality \\
\hline 1. & Attitude1 & .559 & .538 \\
2. & Attitude2 & .699 & .721 \\
3. & Attitude3 & .697 & .746 \\
4. & Attitude4 & .523 & .723 \\
5. & Attitude5 & .795 & .665 \\
6 & SNMS1 & .419 & .747 \\
7 & SNMS2 & .570 & .715 \\
8 & SNMS3 & .517 & .721 \\
9 & PBC1 & .529 & .611 \\
10 & PBC2 & .674 & .494 \\
11 & PBC3 & .700 & .631 \\
12 & PBC4 & .586 & .731 \\
13 & PBC5 & .582 & $\mathbf{. 6 7 8}$ \\
14 & PBC6 & .675 & .650 \\
15 & PBC7 & .702 & .532 \\
16 & EINT1 & .628 & .693 \\
17 & EINT2 & .644 & .654 \\
18 & EINT3 & .752 & .681 \\
19 & EINT4 & .740 & .756 \\
20 & EINT5 & .477 & .723 \\
21 & EINT6 & .764 & .677 \\
\hline
\end{tabular}

SNMS $=$ Subjective Norms, $\mathrm{PBC}=$ Perceived Behavioural Control, EINT $=$ Entrepreneurial Intention

From Table 6 above, all factors have a high factor loading which confirmed that the constructs are measured by different variables as earlier postulated.

4.9 Reliability Analysis

Reliability analysis discloses the degree of which a measure is error free, and unveils the consistency, stability 
and goodness of the measure. The Cronbach alpha is the most generally used technique for the reliability analysis (Cavana et al., 2001). The goal of measuring the Cronbach coefficient alpha is to ascertain the internal consistency of a scale (Sandhu et al., 2011). Cronbach alpha also indicates how the study items are positively correlated to each other (Sekaran, 2003). The closer Cronbach alpha is to 1, the greater the internal consistency (Sandhu et al., 2011). All values of the Cronbach alpha are greater than 0.70 in this study, thus; the instruments are internally consistent. The results of the reliability analysis are depicted in Table 7 below.

Table 7. Cronbach coefficient alpha values for attitude, subjective norms, perceived behavioural control and entrepreneurial intentions

\begin{tabular}{llcc}
\hline S/No & Variables & Items & Cronbach coefficient alpha Values \\
\hline 1. & Attitude & 5 & .783 \\
2. & Subjective Norms & 3 & .791 \\
3. & Perceived Behavioral Control & 7 & .843 \\
4. & Entrepreneurial Intention & $\mathbf{6}$ & $\mathbf{. 8 2 5}$ \\
\hline
\end{tabular}

\section{Conclusion}

The findings of this study show that the data fulfilled the needs and the essential prerequisite to the multivariate analysis stage. This study has removed the multivariate and the univariate outliers as suggested by Tabachnick and Fidell, (2007) and Hair et al. (2010) the data is therefore, turned to a normal distribution. Non-response bias is also not experienced in the study. The data is neat and screened completely thus, ready for multivariable analysis (Tabachnick \& Fidell, 2007). Multicollinearity was also not found to exist in reference to the suggestions of Tabachnick and Fidell, (2007) as well as Hair et al., (2010). The implication of this study is that the data has been made worthy for the most imperious suppositions and needs for the multivariate stage analysis and will provide literature to researchers. The findings will therefore, offer an insight to advance analysis and will provide the understanding of why and how this may be assorted in an intensifying environment viewpoint.

\section{Acknowledgments}

I would like to thank the Kano State Government under the Kwankwasiyya Administration for financing this study through the 501 postgraduate scholarship programme.

\section{References}

Agbim, K. C., Oriarewo, G. O., \& Owocho, M. (2013). Factors Influencing Entrepreneurial Intentions among Graduates of Nigerian Tertiary Institutions. International Journal of Business and Management Invention, 2(4), 36-44.

Ajzen, I. (1991). The Theory of Planned Behaviour. Organizational Behaviour and Human Decision Processes, 50, 179-211. http://dx.doi.org/10.1016/0749-5978(91)90020-T

Ali, A., Topping, K. J., \& Tariq, R. H. (2010). Entrepreneurial attributes among postgraduate students of a Pakistani university. US-China Education Review, 7(5). USA.

Angriawan, A., Conners, S. E., Furdek, J., \& Ruth, D. (2012). An empirical examination of entrepreneurial intent in the equine industry. Proceedings of the Academy of Entrepreneurship, 18(1), 1-8.

Bakotic, D., \& Kruzic, D. (2010). Students' Perceptions and Intentions towards Entrepreneurship: The Empirical Findings from Croatia. The Business Review, Cambridge, 14(2).

Berg, N. (2002). Non-response bias. Retrieved May, 2002, from http://www.utdallas.edu/ nberg/Berg... /BergNon-pdf

Byrne, B. M. (2010). Structural Equation Modeling with AMOS; Basic Concepts, Application and Programming (2nd ed.). Routledge Taylor and Francis Group New York.

Cavana, R. Y., Delahaye, B. L., \& Sekaran, U. (2001). Applied Business Research: Qualitative and Quantitative Methods (3rd ed.). John Wiley \& Sons Australia Ltd.

Davey, T., Plewa, C., \& Struwig, M. (2011). Entrepreneurship perceptions and career intentions of international students. Education + Training, 53(5), 335-352. http://dx.doi.org/10.1108/00400911111147677

Ekpe, I., \& Mat, N. (2012). The Moderating Effect of Social Environment on the Relationship between 
Entrepreneurial Orientation and Entrepreneurial Intentions of Female Students at Nigerian Universities. International Journal of Management Sciences and Business Research, 1(4), 1-16.

Gorondutse, A. H., \& Hilman, H. (2014). Effect of Business Social Responsibility (BSR) on Performance of SMEs: Data Screening and Preliminary Analysis. Asian Social Science, 10(8), 103-115.

Hair, Jr. J. F., Black, W. C., Babin, B. J., \& Anderson, R. E. (2010). Multivariate data analysis (7th ed.). Upper Saddle River, New Jersey: Pearson Education International.

Iakovleva, T., Kolvereid, L., \& Stephan, U. (2011). Entrepreneurial intentions in developing and developed countries. Education \& Training, 53(5), 353-370. http://dx.doi.org/10.1108/00400911111147686

Izedonmi, P. F., \& Okafor, C. (2010). The Effect of Entrepreneurship Education on Students' Entrepreneurial Intentions. Global Journal of Management and Business Research, 10(6), 49-60.

Kaiser, H. F. (1970). A second generation Little Jiffy. Pchometrika, 35, 401-415. http://dx.doi.org/10.1007/BF 02291817

Kaiser, H. F. (1974). An index of factorial simplicity. Pchometrika, 39, 31-36. http://dx.doi.org/10.1007/BF 02291575

Karabulut, A. T. (2014). Entrepreneurial Career Intentions of Alumni: A Study in a Turkish Foundation University. International Journal of Business and Management, 9(2), 30-44. http://dx.doi.org/10.5539/ijbm. v9n2p30

Kautonen, T., Marco, G. V., \& Erno, T. (2012). Predicting entrepreneurial behaviour: A test of the theory of planned behaviour. Journal of Applied Economics, 45(6), 697-707. http://dx.doi.org/10.1080/00036846. 2011. 610750

Kolvereid, L., \& Isaksen, E. (2006). New business start-up and subsequent entry in to self-employment. Journal of Business Venturing, 21, 866-885. http://dx.doi.org/10.1016/j.jbusvent.2005.06.008

Krejcie, R. V., \& Morgan, D. W. (1970). Determining Sample Size for Research Activities. Educational and psychological measurement, 30, 607-610.

Krueger, N., Reilly, M. D., \& Carsrud, A. L. (2000). Competing models of entrepreneurial intentions. Journal of Business Venturing, 15, 411-432. http://dx.doi.org/10.1016/S0883-9026(98)00033-0

Kuttim, M., Kallastea, M., Venesaara, U., \& Kiis, A. (2014). Entrepreneurship education at university level and students' entrepreneurial intentions. Contemporary Issues in Business, Management and Education 2013, Procedia-Social and Behavioral Sciences, 110, 658-668.

Liñán, F., \& Chen, Y. (2009). Development and cross-cultural application of a specific instrument to measure entrepreneurial intentions. Entrepreneurship Theory \& Practice, 5, 593-617.

Liñán, F., Nabi, G., \& Krueger N. (2013). British and Spanish entrepreneurial intentions a comparative Study. Revista de economía Mundial, 33, 73-103.

Liñán, F., Rodriguez-Cohard, J. C., \& Rueda-Cantuche, J. M. (2011). Factors affecting entrepreneurial intention levels a role for education. International Entrepreneurship and Management Journal, 7, 195-218. http://dx.doi.org/10.1007/s11365-010-0154-z

Mahmoud, M. A., \& Muharam, F. M. (2014). Factors Affecting the Entrepreneurial Intention of PhD Candidates: A study of Nigerian International Students of UUM. European Journal of Business and Management, 6(36), 17-24.

Maiyaki, A. A., \& Mouktar, S. S. M. (2011). Influence of service quality, corporate image and perceived value on customer behavioral responses in Nigerian Banks: Data screening and preliminary analysis. International Conference on Management Proceeding, 547-568.

Malebana, J. (2014). Entrepreneurial intentions of South African rural university students: A test of the theory of planned behaviour. Journal of Economics and Behavioural Studies, 6(2), 130-143.

Mueller, S. (2011). Increasing entrepreneurial intention: Effective entrepreneurship course characteristics. International Journal of Entrepreneurship \& Small Business, 13(1), 55-74. http://dx.doi.org/10.1504/IJESB. 2011.040416

Nabi, G., \& Linan, F. (2011). Graduate entrepreneurship in the developing world: Intentions, education and development. Education \& Training, 53(5), 325-334. http://dx.doi.org/10.1108/00400911111147668 
Nunnally, J. C., \& Bernstein, I. H. (1994). Psychometric theory (3rd ed.). New York: McGraw Hill.

Ogundipe, S. E., Kosile, B. A., Olaleye, V. I., \& Ogundipe, L. O. (2012). Entrepreneurial Intention among Business and Counselling Students in Lagos State University Sandwich Programme. Journal of Education and Practice, 3(14).

Otuya, R., Kibas, P., Gichira, R., \& Martin, W. (2013). Entrepreneurship education: Influencing students' entrepreneurial intentions. International Journal of Innovative Research \& Studies, 2(4), 132-148.

Owoseni, O. O. (2014). The Influence of Some Personality Factors on Entrepreneurial Intentions. International Journal of Business and Social Science, 5(1), 278-284.

Owoseni, O. O., \& Akambi, P. A. (2010). Entrepreneurial Intentions: A Theoretical Framework. Journal of management and corporate governance, 2(4), 132-148.

Sahinidis, A. G., Giovanis, A. N., \& Sdrolias, L. (2012). The Role of Gender on Entrepreneurial Intention Among Students: An Empirical test of the Theory of Planned Behaviour in a Greek University. International Journal on Integrated Information Management, 1(1), 61-79.

Sandhu, M. S., Sidique, F. S., \& Riaz, S. (2011). Entrepreneurship barriers and entrepreneurial inclination among Malaysian postgraduate students. International Journal of Entrepreneurial Behaviour \& Research, 17(4), 428-449. http://dx.doi.org/10.1108/13552551111139656

Sekaran, U. (2003). Research Methods for Business: A Skill-Building Approach. John Wiley \& Sons, New York, NY.

Sheikh, K. (1981). Investigating non-response bias in mail surveys. Journal of Epidemiology and Community Health, 35, 293-296. http://dx.doi.org/10.1136/jech.35.4.293

Singer, E. (2006). Non-response bias in household surveys. Public Opinion Quarterly, 70(5), 637-645. http://dx.doi.org/10.1093/poq/nfl034

Souitaris, V., Zerbinati, S., \& Al Laham, A. (2007). Do Entrepreneurship Programmes raise Entrepreneurial Intention of Science and Engineering Students? The Effect of Learning, Inspiration and Resources. Journal of Business venturing, 22, 566-591. http://dx.doi.org/10.1016/j.jbusvent.2006.05.002

Tabachnick, B. G., \& Fidell, L. S. (2007). Using multivariate statistics (5th ed.). Boston: Pearson Education, Inc.

Uddin, M. R., \& Bose, T. K. (2012). Determinants of Entrepreneurial Intention of Business Students in Bangladesh. International Journal of Business and Management, 7(24), 128-137. http://dx.doi.org/10.5539/ ijbm.v7n24p128

Zampetakis, A. L., Anagnosti, A., \& Rozakis, S. (2013). Understanding entrepreneurial intentions of students in agriculture and related sciences. AUA Working Paper Series No. 2013-4 Agricultural University of Athens Department of Agricultural Economics \& Rural Development. Retrieved from http://www.aoa.aua.gr

\section{Copyrights}

Copyright for this article is retained by the author(s), with first publication rights granted to the journal.

This is an open-access article distributed under the terms and conditions of the Creative Commons Attribution license (http://creativecommons.org/licenses/by/3.0/). 